\title{
MEMBANGUN MUTU PENDIDIKAN KARAKTER SISWA MELALUI IMPLEMENTASI AJARAN TRI HITA KARANA
}

\author{
Oleh \\ Kadek Arta Jaya \\ SMKN 5 Denpasar \\ artakertawijaya@gmail.com
}

diterima 10 Januari 2019, direvisi 12 Februari 2019, diterbitkan 28 Februari 2019

\begin{abstract}
Building the character and character of the nation through education is absolutely necessary, starting from family education, school and society. In the family character education should be a school of love, where the family becomes a place of learning for their children who are full of love and affection from their parents. Character education through school is not merely just giving knowledge learning, but more about moral understanding, ethical values, noble character and so on. While character education in the community by imitating community leaders is exemplary by children. In the education process the implementation of the Tri Hita Karana concept can provide an influence on learning outcomes, because one of the concepts of Tri Hita Karana is to maintain harmony with fellow friends and obey religious orders and the teacher will be able to provide a better result in achieving cognitive aspects, psychomotor aspects, and apective aspects that are able to provide guidance for life to students. Students will become more obedient to school discipline, increase respect for teachers or older people, foster a sense of devotion to God Almighty and have a sense of care for the environment.
\end{abstract}

\section{Keywords : Pendidikan, Karakter, Tri Hita Karana}

\section{PENDAHULUAN}

Kondisi masyarakat Indonesia pada saat ini menunjukkan bahwa telah terjadi suatu keguncangan yang cukup mengerikan dalam perkembangan peradaban bangsa kita. Nilai-nila fundamental seperti penghargaan atas hak hidup seseorang ternyata sudah tidak lagi dijadikan landasan dalam bertindak oleh berbagai kelompok masyarakat di berbagai wilayah Indonesia. Rasa kasih sayang antara sesama mahkluk ciptaan Tuhan Yang Maha Esa diganti dengan kebencian yang dilancarkan oleh berbagai kelompok etnis, pemeluk agama, anggota partai politik, bahkan oleh komunitas yang secara historis terkenal memiliki jiwa gotong royong yang tinggi, yakni masyarakat desa atau kampung. 
Untuk mengatasi hal tersebut di atas, maka perlu dilakukan kembali penanaman nilai-nilai agama dan budaya serta pendidikan karakter kembali melalui proses pembelajaran. Pembangunan karakter merupakan upaya mewujudkan amanat Pancasila dan pembukaan UUD 1945 dilatar belakangi oleh realita permasalahan kebangsaan yang berkembang saat ini, seperti: disorientasi dan kurang dihayatinya nilai-nilai Pancasila; bergesernya nilai etika dalam kehidupan berbangsa dan bernegara; memudarnya kesadaran terhadap nilai-nilai budaya bangsa, ancaman disintergrasi bangsa dan melemahnya kemandirian.

Konsep Tri Hita Karana dikelompokkan dalam tiga nilai yaitu: (1) akhlak terhadap Tuhan Yang Maha Esa (Parhyangan), (2) akhlak terhadap manusia (Pawongan), dan (3) akhlak terhadap lingkungan (Palemahan). Dalam menghadapi kehidupan yang pundamentalis, konsep ajaran Tri Hita Karana memperkenalkan nilai-nilai realitas hidup bersama dalam hal penanaman nilai-nilai religius, pembudayaan nilai sosial, penghargaan gender, penanaman nilai keadilan, pengembangan sikap domokratis, penanaman sikap kejujuran, menunjukkan sikap kejujuran, peningkatan sikap dan daya juang, pengembangan sikap tanggung jawab, dan penghargaan terhadap lingkungan alam.

\section{PEMBAHASAN}

\section{A. Kemitraan antara Sekolah dan Keluarga}

Kerja sama antara sekolah dan keluarga perlu ditingkatkan supaya tidak terjadi kontradiksi atau ketidakselarasan antara nilai-nilai yang harus dipegang teguh oleh anak-anak disekolah dan yang harus mereka ikuti di lingkungan keluarga ataupun di lingkungan masyarakat tempat keberadaan si anak. Apabila terjadi konflik nilai, anakanak mungkin akan merasa binggung sehingga tidak memiliki pegangan nilai yang menjadi acuan dalam berperilaku. Akibatnya, mereka tidak mampu mengontrol diri dalam menghadapi pengaruh negatif dari lingkungan sekitar mereka.
Pola kemitraan yang dilakukan oleh guru disekolah dengan orang tua siswa yang bagaimana kiranya yang efektif, dalam rangka pendidikan Karakter dan spiritualitas bagi siswa disekolah? Kemitraan yang perllu dilakukan tentu saja bukan yang bersifat formal berupa adanya penandantanganan surat perjanjian atau yang serupa dengan itu, tetapi yang secara alami dan berkesinambungan dapat menyatukan langkah dalam mendidik putra-putri bangsa Indonesia. Penciptaan suasana yang kondusif bagi pendidikan Karakter dan spirirtualitas, baik di sekolah maupun di rumah, tampaknya merupakan ssalah satu bentuk kemitraan yang perlu dikembangkan oleh guru di sekolah dengan orang tua siswa (Zuchdi, 2010:133-134).

Suasana kehidupan di sekolah dan di rumah memengaruhi terhadap perkembangan kepribadian anak, karena hal itu merupakan wahana penyemaian nilai-nilai yang akan dijadikan acuan oleh siswa /anak dalam setiap tindakannya. Apabila para siswa merasa tentram berada di sekolah, demikian juga ketika tinggal di rumah, mereka dapat diharapkan memiliki dorongan yang kuat untuk melaksanakan tugas sekolah dan tugas rumah dengan sebaik-baiknya. Sehingga dengan demikian anak-anak akan dengan sukarela menerima dan mengamalkan nilaiKarakter positif yang menjadi keyakinan mereka beserta seluruh anggota keluarga. Namun sebaliknya, jika anak-anak merasa tidak tenang dan gelisah dalam menghadapi pertentangan, atau tidak dipedulikan, perkembangan intelektual dan emosional mereka akan dapat menghampat perkembangan belajarnya. Sehingga akan berakibat pada nilai-Karakter positif akan mereka abaikan dan nilai-nilai negatif akan mereka jadikan landasan dalam berperilaku.

Suasana kelas atau sekolah yang positif akan dapat memungkinkan siswa dapat mengembangkan nilai-Karakter yang fundamental yang sangat diperlukan di dalam kehidupan sosial siswa itu sendiri. Nilai-Karakter tersebut antara lain adalah nilai kasih sayang antar sesama umat, kemauan untuk mencapai yang terbaik 
dengan cara-cara yang di anugrahi oleh Tuhan Yang Maha Esa, dan kesenangan bekerja sama dengan sesama teman untuk mencapai kemajuan belajar bersama. Nilainilai inilah yang merupakan prasyarat bagi terbangunnya generasi yang cerdas dan berakhlak mulia, maju dan damai (Zuchdi, 2010)

Para guru dan orang tua yang ingin mengembangkan suasana positif di sekolah dan di lingkungan keluarga harus mampu memberikan dorongan kepada anak-anaknya untuk mengembangkan dan mengungkapkan gagasan serta perasaan mereka sendiri, membuat keputusan sendiri, dan berpartisipasi dalam menentukan tujuan belajar secara prosedur pencapaiannya. Peran guru-guru dan para orang tua dalam menanamkan nilai-Karakter dan spiritualitas kepada anak dirumah dan siswa disekolah juga dapat mengatur suasana kelas atau keluarga sedemikian rupa sehingga anakanak dapat mendiskusikan masalah masingmasing secara bersama-sama.

Untuk menerapkan pendidikan Karakter tentunya tidak bisa dilakukan hanya oleh satu pihak saja. Ketika guru membentuk Karakter pada diri anak, sedangkan di lingkungan masyarakat ia melihat banyak nilai-nilai yang dilanggar, maka hanya ada dua kemungkinan, ia tetap berpegang teguh pada nilai-nilai yang telah dipelajari di sekolah, atau ia menanggalkan nilai-nilai tersebut dan mengikuti pelanggaran nilainilai yang terjadi di masyarakat. Oleh sebab itu untuk membentuk pribadi yang unggul dan berkarakter diperlukan kerja sama dan koordinasi antara sekolah, keluarga, dan anggota masyarakat.

Untuk mencapai suatu kesukesan dalam memberikan nilai pada siswa tentunya dari awal kita bentuk dulu Karakter pada diri kita. Mungkin masih ada guru yang mengingatkan siswanya untuk jangan terlambat ke sekolah namun ia sendiri terlambat ke sekolah, masih ada guru yang mengingatkan siswa agar tidak berkonflik dengan sesama siswa namun ia sendiri terlibat konflik dengan sesama pendidik. Tidak akan efektif suatu pendidikan jika pendidik tidak terdidik dan tidak akan dikatakan berhasil suatu pendidikan jika pendidik tidak memiliki dimensi keikhlasan.

Perlu diingat bahwa untuk mengubah ataupun membentuk sistem nilai pada diri anak dibutuhkan proses, tidak bisa secara instan kita bentuk karakter tersebut, oleh sebab itu baik orang tua, guru di sekolah maupun masyarakat luas perlu kesabaran dan upaya ekstra dalam membentuk pribadi yang berkarakter. Ketika penanaman karakter dikatakan berhasil pada remaja, kelak merekalah yang akan membangun tanah air menjadi maju dan tetap berpegang teguh pada nilai agama, moral, dan aturan kehidupan bermasyarakat dan bernegara melalui cerminan etika, moral, budi pekerti, dan ditandai dengan samangat, tekad, dan energi yang kuat, dengan pikiran positif dari sikap yang optimis.

\section{1). Tanggung jawab Sekolah dan Orang Tua dalam Pendidikan Karakter}

Sekolah menjadi lembaga pendidikan sebagai media berbenah diri dan membentuk nalar berpikir yang kuat dengan ilmu pengetahuan dan teknologi serta untuk membentuk Karakter peserta didik dengan nilai-nilai luhur. Sedangkan keluarga merupakan tempat pendidikan anak yang pertama dan utama sehingga antara sekolah dan keluarga mempunyai tanggung jawab yang sama untuk membentuk karakter anakanak agar menjadi manusia yang seutuhnya dengan berbagai kompetensi yang dimilikinya dan mempunyai akhlak mulia.

Sekolah merupakan wahana yang mencerdasakan dan memberikan perubahan kehidupan bagi anak-anak didik. Dengan kata lain, sekolah mampu memberikan warna baru bagi kehidupan anak ke depannya, sebab di sekolah mereka ditempa untuk belajar berbicara, berpikir, dan bertindak. Sedangkan dirumah anak didik dengan sopan santun, didik untuk menghormati guru sehingga tanggung jawab keluarga sangat dominan di dalam mendidik anak-anak menjadi berkarakter. Di sekolah anak-anak di didik untuk menjadi dirinya sendiri. Jika antara sekolah dan orang tua siswa telah 
melaksanakan tugas dan tanggung jawab maka akan berhasil di dalam membangun Karakter anak-anak menjadi generasi yang cerdas.

Sekolah bertanggung jawab menanamkan pengetahuan-pengetahuan baru yang reformatif dan transformative dalam membangun karakter siswa menjadi cerdas, berakhlak mulia, bertanggung jawab, dan mandiri. Sementara tugas orang tua dari peserta didik adalah menanamkan nilaiKarakter sejak dini dikeluarga agar anakanak setelah memasuki lingkungan sekolah formal menjadi cerdas dan selalu menghormati guru. Sebab jika di keluarga anak-anak sudah terbiasa disiplin dan hormat sama orang tua maka disekolah anak-anak akan tetap membawa sikap dan sifat yang telah ditanamkan oleh orang tuanya.

Dengan demikian peran guru dan orang tua di dalam menanamkan nilaiKarakter pada anak-anak sangat besar perannya dalam menentukan arah dan orientasi peserta didik kedepannya. Dengan adanya tanggung jawab antara sekolah dan orang tua dalam mendidik anak-anak maka anak akan mempunyai kecerdasan intelektual, emosional, dan spiritual yang tinggi sebagai bekal untuk melanjutkan dan memperjuangkan agamanya (Wiyani, 2012).

\section{2). Sekolah sebagai Wahana Pendidikan Karakter Siswa}

Sekolah sebagai wahana atau tempat anak untuk berproses mengalami suatu perubahan dalam tingkah lakunya. Proses perubahan tingkah laku dan religiusitas dalam diri siswa sesuai dengan nilai-nilai sosial dan kebudayaan yang tertuang dalam kurikulum yang dibuat oleh sekolah. Kurikulum pendidikan yang dilaksanakan oleh guru, salah ssatunya dapat berfungsi untuk membentuk tingkah laku dan spiritualitas siswa menuju kepribadian yang dewasa secara optimal. Di sekolah adalah tempat berlangsungnya proses transformasi nilai-nilai luhur karakter dan spiritualitas siswa melalui pembelajaran atau pendidikan. Pendidikan Karakter dan spiritual merupakan kata kunci dari transformasi nilai-nilai luhur di sekolah. Guru menjadi transformer nilainilai luhur kepada peserta didik untuk menjadi bagian dari masyrakat yang berbudaya.

Wiyani (2012:35) menyatakan bahwa ada beberapa fungsi transformasi nilai-nilai luhur yang dilaksanakan oleh sekolah mencakup lima dimensi, yaitu:

1. Pendidikan tidak hanya mencakup pengetahuan dan keterampilan semata tetapi juga sikap, nilai, dan kepekaan pribadi.

2. Peran seleksi sosial (mencakup tidak hanya pemberian sertifikat, tetapi juga melakukan seleksi terhadap peluang kerja).

3. Fungsi pemeliharaan anak.

4. Aktivitas kemasyarakatan.

Sehingga dapat kita katakan bahwa sekolah mempunyai fungsi pendidikan, peran sosial, pemeliharaan, dan aktivitas kemasyarakatan. Sekolah sebagai wahana transformasi nilai-Karakter dan spiritualitas dan pengetahuan siswa akan menentukan corak berpikir dan berperilaku yang sesuai dengan norma-norma agama yang diyakini dan dimiliki oleh masyarakat. Sehingga pada gilirannya, kepribadian siswa akan terbentuk sesuai dengan akar budayanya dengan kemampuan merespons perubahan di masyarakat.

\section{B. Implementasi Ajaran Tri Hita Karana Sebagai Upaya Membangun Karakter Siswa di Sekolah}

Istilah Tri Hita Karana belum pernah penulis jumpai dalam berbagai sumber ajaran Agama Hindu, seperti Veda Sruti maupun kitab-kitab Sastranya. Secara etimologis bahasa Sansekerta istilah Tri Hita Karana berasal dari kata "tri, hita dan Karana". Tri artinya tiga, Hita artinya bahagia dan Karana artinya penyebab. Dengan demikian Tri Hita Karana sebagai istilah berarti "tiga penyebab kebahagiaan". Konsep Tri Hita Karana inilah yang dijadikan dasar untuk mengajarkan manusia agar mampu mengupayakan hubungan yang harmonis dengan Tuhan, dengan sesama manusia dan dengan alam lingkungannya. Ini 
artinya Tri Hita Karana sudah ada dalam kitab suci dan kitab sastra Hindu, tetapi nama Tri Hita Karana adalah sebutan baru untuk menamakan ajaran yang sudah ada dalam kitan suci Hindu (Wiana, 2007:5-6).

Menurut konsep ajaran Tri Hita Karana bahwa alam semesta ini pada mulanya memiliki asal yang sama (yakni Tuhan). Alam semesta ini dipandang berasal dari satu garbha "kandungan yang mahabesar" dari Tuhan Yang Maha Kuasa, sebagaimana dinyatakan didalam Bhagawad Gītā Bab VII. Sloka 6 sebagai berikut:

"etad-yonīni bhūtāni sarvānuity upadhāraya, aham krtsnasya jagatah prabhavah pralayas tath $\overline{\bar{a}}$

Terjemahan :

Ketahuilah bahwa semua makhluk yang ada (di dunia ini) berasal dari garbha (kandungan) $\mathrm{Ku}$, Aku adalah asal mula dan pelebur alam semesta ini” (Pudja, 1999:187).

Berdasarkan pada konsep-konsep dasar di atas, maka sangat pantaslah jika sebagai manusia harus memiliki dan membangun hubungan yang harmonis dan selaras dengan rencana Tuhan. Dengan konsep tersebut, maka terbangunlah satu macam hubungan antara manusia dengan Tuhan, selanjutnya, karena manusia diciptakan tidak dalam keadaan sendirian, melainkan berbagai komunitas makhluk, maka manusia juga harus membangun hubungan yang harmonis dengan berbagai komunitas makhluk itu. Oleh karena itulah maka terbangunlah macam hubungan antara manusia dengan dengan makhluk lain atau dengan alam sekitarnya. Demikian pula antara sesama manusia juga harus terbagun pola hubungan yang harmonis. Dengan demikian sudah terbangun hubungan antara manusia dengan manusia (Donder, 2007:400).

Sehingga konsep Tri Hita Karana yang sudah dijelaskan di atas baik dari sloka kitab suci maupun pendapat ahli, dapat dinyatakan bahwa pola hubungan yang diciptakan dalam konsep Tri Hita Karana dalam membangun Karakter dan spiritualitas siswa disekolah agar selalu berintikan pada prinsip dasar adanya unsur keke-Tuhan-an. Artinya bahwa hubungan Tri Hita Karana dalam membangun Karakter dan spiritualitas siswa disekolah agar selalu bertitik tolak pada adanya suatu keyakinan bahwa: (1) semua aktivitas manusia berdasarkan pada ajaran yang bersumber dari Tuhan; (2) semua aktivitas manusia diketahui dan disaksikan oleh Tuhan; (3) semua aktivitas manusia ditujukan sebagai persembahan kepada Tuhan. Dengan memperhatikan pola hubungan yang diformat dalam konsep Tri Hita Karana yang demikian itu, maka secara konsepsional menjamin terwujudnya siswa yang religius, agamais, jujur, setia, berakhlak mulia, bertanggung jawab, bermoral, beretika, sopan santun, welas asih, kasih sayang dan mencintai semua ciptaan Tuhan.

Jika semua siswa mampu membina keharmonisan ini dengan disiplin yang tinggi sesuai dengan kewajiban masing-masing, maka karakter siswa akan menjadi kuat didalam menghadapi persaingan hidup dizaman modern ini. Berikut ini dikutipkan ajaran tentang disiplin didalam kitab Atharvaveda sebagai landasan membentuk Karakter dan spiritualitas serta mengembangkan tanggung jawab bersama yang mesti dan patut diikuti oleh setiap anggota siswa disekolah:

"Tuhan Yang Maha Esa menciptakan manusia supaya hidup serasi, menjauhkan diri dari perbuatan buruk, hendaknya seseorang mampu mengendalikan diri dan memiliki disiplin yang tinggi sehingga tumbuh keselarasan, saling pengertian dan tanggung jawab bersama sebagai seorang siswa" (Atharvaveda III.8.5).

Berdasarkan kutipan sloka Atharvaveda di atas, sangat relevan dengan konsep Tri Hita Karana dimana Tri Hita Karana mengandung nilai-Karakter yang sangat relevan untuk diterapkan didalam proses pendidikan untuk membentuk 
karakter dan spiritualitas siswa disekolah. Tri Hita Karana seharusnya lebih dipahami sebagai filosofi hidup untuk mewujudkan sikap hidup seimbang dan konsisten untuk percaya dan bhakti pada Tuhan, mengabdi pada sesama manusia dan memelihara kesejahteraan alam lingkungan. Tri Hita Karana tidak bisa dipahami sepotongpotong. Tri Hita Karana sebagai suatu kesatuan yang utuh, sinergis dan konsisten sebagai filosofi hidup universal.

Dalam proses pendidikan ajaran $T r i$ Hita Karana merupakan sebuah konsep yang sangat monumental dan bersifat adiluhung dalam membangun keharmonisan yang penuh dengan nilai-nilai kebajikan, nilai moral, nilai etika, nilai persatuan sehingga terjadi kehidupan yang harmonis antara semua ciptaan Tuhan. Pancaran nilai pendidikan yang sangat tinggi memberikan daya tarik yang sangat kuat bagi para penyelenggara pendidikan untuk mengangkatnya sebagai sumber inspirasi dalam proses peningkatan mutu pendidikan dalam upaya mewujudkan out-put yang berkualitas dan berkarakter. Pendidikan sains dan teknologi sekarang ini lebih berorientasi pada penguasaan ilmu (aspek kognitif) dan penguasaan keterampilan (aspek psikomotorik) dan aspek afektif yang menyangkut sikap, perilaku, moral, budi pekerti, hampir terabaikan padahal aspek afektif ini sangat penting untuk membangun kepribadian siswa secara utuh. Jika aspek afektif ini dijadikan tujuan dalam proses pendidikan maka tujuan pendidikan karakter dan spiritualitas akan tercapai dengan baik.

Aspek afektif dapat dibentuk melalui implementasi konsep ajaran Tri Hita Karana disekolah, karena konsep ajaran Tri Hita Karana juga merupakan bagian dari materi pembelajaran pendidikan agama Hindu. Pendidikan agama Hindu merupakan bagian dari rumpun atau kelompok mata pelajaran agama dan akhlak mulia yang dimaksudkan untuk membentuk peserta didik menjadi manusia yang beriman dan bertakwa kepada Tuhan Yang Maha Esa serta berakhlak mulia. Akhlak mulia mencakup etika, budi pekerti atau moral sebagai perwujudan dari pendidikan agama (Peraturan Menteri Pendidikan Nasional RI No.22 tahun 2006 tentang Standar Isi) yang sangat erat kaitannya dengan pembentukan dan pembangunan karakter bangsa.

Sekolah sebagai lembaga pendidikan formal yang paling strategis sebagai pusat budaya sangat tepat untuk mengimplementasikan konsep Tri Hita Karana dalam membangun Karakter dan spiritualitas siswa. Menurut Megawangi (2004:95) pendidikan karakter adalah sebuah usaha untuk mendidik anak-anak agar dapat mengambil keputusan dengan bijak dan mempraktikkannya dalam kehidupan seharihari, sehingga mereka dapat memberikan kontribusi yang positif kepada lingkungannya. Sementara menurut Fakry Gaffar (dalam Syarbini, 2012:17) menyatakan bahwa pendidikan karakter adalah sebuah proses transformasi nilai-nilai kehidupan untuk ditumbuhkembangkan dalam kepribadian seseorang, sehingga menjadi satu dalam perilaku kehidupan orang itu.

Dalam hal ini pendidikan karakter merupakan suatu sistem penanaman nilaiKarakter kepada warga sekolah yang meliputi komponen pengetahuan, kesadaran atau kemauan, dan tindakan untuk melaksanakan nilai-nilai tersebut baik hubungan dengan Tuhan Yang Maha Esa, baik pada diri sendiri, sesama manusia, sesama lingkungan maupun kebangsaan sehingga menjadi insan cerdas dan spiritual. Dalam pendidikan karakter disekolah, semua komponen (stake holders) harus dilibatkan termasuk komponen-komponen pendidikan itu sendiri yang meliputi: isi kurikulum, proses pembelajaran dan penilaian, kualitas hubungan, penanganan atau pengelolaan mata ajar, pengelolaan sekolah, pelaksanaan aktivitas atau kegiatan ko-kurikuler, pemberdayaan sarana prasarana, pembiayaan dan etos kerja seluruh warga dan lingkungan sekolah.

Jika konsep ajaran Tri Hita Karana dapat diimplementasikan sebagai landasan pendidikan pada setiap pembelajaran khususnya mata pelajaran agama maka akan 
dapat membangun hubungan manusia secara harmonis, demokratis, empatik, dan simpatik, menjunjung tinggi nilai-nilai kehidupan dan hak asasi manusia, jujur, percaya diri, cinta kasih, berdisiplin, menghargai perbedaan dalam masyarakat berbangsa dan bernegara. Dengan demikian sudah semakin jelas bahwa implementasi konsep Tri Hita Karana dalam membangun karakter manusia sangat penting dan akan sejalan dengan perkembangan kecerdasan yang lain, karena penguasaan ilmu pengetahuan dan teknologi tanpa dilandasi dengan kecerdasan emosional, kecerdasan sosial, dan kecerdasan spiritual akan menghasilkan karya-karya tanpa nilai berarti dan tidak bermanfaat bagi kehidupan manusia.

\section{Tujuan dan Fungsi Penanaman Karakter Siswa Melalui Implementasi Tri Hita Karana}

Pendidikan agama Hindu memuat kajian komprehensif akan peran dan fungsinya dalam kehidupan modern yang pluralistik dan turbulent. Kehidupan untuk masa depan yang disadari dari penghayatan masa kini dan masa lalu. Pola pewartaan pendidikan agama Hindu bertumpu pada pencapaian kedamaian yang diformulasikan dengan pernyataan Moksartam Jagadhitaya ca iti Dharma. Dasar pijak gerak dalam pendidikan agama Hindu adalah Satyam (Kebenaran, kejujuran), Sivam (Kebajikian), Sundaram (Kedamaian) dalam membangun keharmonisan tiga pola hubungan yang dikenal dengan konsep Tri Hita Karana. Kebenaran harus dinyatakan dengan penuh kebajikan agar terbangun kedamaian dan keharmonisan. Berikut ini penulis petikkan beberapa mantram-mantram Veda yang menguraikan ajaran kebenaran, kejujuran, akhlak mulia, kasih sayang dan keharmonisan.

"Agne vratapate vratam carişāmi tacchakeyam. Tam-me rādhyatām. Idam aham anritāt satyam upaimi”.

(Yajurveda. I. 5)

Terjemahan :
'Ya Sang Hyang Agni, penguasa peraturan-peraturan suci, kami akan menjalankan janji kebenaran itu. Semoga kami dimahkotai dengan keberhasilan dalam menjalankan janjiku. Kami menderapkan langkah dengan tegap pada jalan kebenaran, dengan menahan diriku sendiri dari kebohongan (dusta).

Pada tataran sekolah perilaku tersebut di atas perlu dibudayakan agar dapat di internalisasi sebagai kepribadian peserta didik baik dalam proses pembelajaran maupun dalam kegiatan ekstra kurikuler, sehingga peserta didik dalam mengambil keputusan sehari-hari dapat mempertimbangkan dan berorientasi terhadap nilai-Karakter yang telah membudaya dilingkungan sekolah.

Tujuan pendidikan pada umumnya seperti apa yang dijelaskan oleh Swami Sathya Narayana (dalam Titib, 2006:21) adalah untuk "membentuk karakter" (character building). Beliau mengatakan antara lain "tujuan pendidikan adalah kearifan, tujuan peradaban adalah kesempurnaan, tujuan kebijaksanaan adalah kebebasan, dan tujuan pendidikan adalah karakter yang baik". Dalam proses pembelajaran dan pembudayaan nilaiKarakter yang terkandung dalam konsep ajaran Tri Hita Karana seharusnya dioptimalisasi untuk mengembangkan potensi peserta didik. Pendidikan karakter berfungsi untuk: (1) membangun kehidupan kebangsaan yang multikultural; membangun peradaban bangsa yang cerdas, berbudaya luhur, dan mampu berkontribusi terhadap pengembangan kehidupan umat manusia, mengembangkan potensi dasar agar berhati baik, berpikiran baik dan berperilaku yang baik serta keteladanan baik; (3) membangun sikap warganegara yang cinta damai, kreatif, mandiri, dan mampu hidup berdampingan dengan bangsa lain dalam satu harmoni (Depdiknas, 2011).

Melalui implementasi ajaran Tri Hita Karana diharapkan mampu membangun karakter peserta didik disekolah menjadi 
anak-anak yang cerdas dan mempunyai akhlak mulia, bersikap religius, peduli terhadap lingkungan, peduli terhadap sesama. Dimana fungsi pendidikan nasional dirumuskan untuk mengembangkan kemampuan dan membentuk watak serta peradaban bangsa yang bermartabat dalam rangka mencerdaskan kehidupan bangsa. Berdasarkan komitmen tersebut maka dirumuskanlah tujuan pendidikan karakter secara umum yaitu untuk membangun dan mengembangkan karakter peserta didik pada setiap jalur, jenis, dan jenjang pendidikan agar dapat menghayati dan mengamalkan nilai-nilai luhur menurut ajaran agama dan nilai-nilai luhur setiap butir sila dari Pancasila. Sedangkan tujuan pendidikan karakter secara khusus adalah untuk mengembangkan potensi peserta anak didik agar berhati baik, berpikiran baik, berkelakuan baik, memiliki sikap percaya diri, bangga pada bangssa dan negara, dan mencintai sesama umat manusia (Amin, 2011:36-37).

Tujuan pendidikan karakter melalui implementasi ajaran Tri Hita Karana adalah untuk membentuk manusia yang mempunyai kepribadian yang luhur dan mempunyai budi pekerti yang tinggi, selalu hidup harmonis dengan sesama manusia, dengan alam sekitarnya maupun adanya keharmonisan hubungan manusia dengan penciptanya yaitu Tuhan Yang Maha Esa. Sehingga setiap manusia pada akhirnya mendapatkan kebahagiaan lahir maupun batin. Dengan karakter mulia setiap usaha dan kegiatan yang dilakukan oleh manusia akan mendapatkan ketentraman, keamanan serta kedamaian hidup "jagadhita" (Titib, 2006:20-21).

Melalui implementasi ajaran Tri Hita Karana maka tujuan dan fungsi pendidikan karakter akan dapat tercapai seperti : (1) mendorong tercapainya keberhasilan belajar peserta didik, serta bertujuan untuk mendewasakan peserta didik agar memiliki kepekaan terhadap nilai-nilai moral yang paripurna, serta seimbang antara kecerdasan intelektual, emosional, dan spiritual; (2) bagi para pendidik/guru diharapkan menjadi primer efek, yang dapat memberi serta menjadikan dirinya suri teladan bagi semua lingkungan sekolah, terutama kepada siswa/peserta didik; (3) dapat menciptakan manusia indonesia yang seutuhnya, yaitu manusia yang beriman dan bertakwa kepada Tuhan Yang Maha Esa, berakhlak mulia, memiliki tangging jawab tinggi dalam menjalankan kehidupan ini; (4) untuk dapat menumbuhkembangkan kemampuan dasar dari peserta didik agar selalu berpikir cerdas, bersikap religius, berperilaku yang berakhlak mulia, mencintai sesama manusia, bermoral, peduli terhadap lingkungan, berbuat sesuatu yang baik yang bermanfaat bagi diri sendiri, keluarga, dan masyarakat, membangun kehidupan bangsa yang multikultur, membangun peradaban bangsa yang cerdas, berbudaya yang luhur, membangun sikap warga negara yang cinta damai, kreatif, mandiri, maupun hidup berdampingan dengan bangsa lain; dan (5) untuk membentuk manusia yang mempunyai kepribadian yang luhur dan mempunyai budi pekerti yang tinggi, selalu hidup harmonis dengan sesama manusia, dengan alam sekitarnya maupun adanya keharmonisan hubungan manusia dengan penciptanya yaitu Tuhan Yang Maha Esa. Sehingga setiap manusia pada akhirnya mendapatkan kebahagiaan lahir maupun batin. Dengan karakter mulia setiap usaha dan kegiatan yang dilakukan oleh manusia akan mendapatkan ketentraman, keamanan serta kedamaian hidup "jagadhita".

\section{Proses Penanaman Karakter dan Spiritualitas Siswa Melalui Implementasi Tri Hita Karana

Menurut pandangan teori

Konstruktivisme belajar akan efektif apabila didasarkan pada empat komponen dasar dalam proses pembelajaran pada peserta didik yaitu: (1) pengetahuan (knowledge), yaitu pembelajaran harus mampu dijadikan sarana untuk tumbuh kembangnya pengetahuan bagi siswa; (2) ketrampilan (skill), yaitu pembelajaran harus benar-benar memberikan ketrampilan siswa baik ketrampilan intelektual (kognitif), 
ketrampilan moral (afektif) dan ketrampilan mekanik (psikomotorik); (3) sifat alamiah (dispositions), yaitu proses pembelajaran harus benar-benar berjalan secara alamiah, tanpa ada paksaan dan tindakan semata-mata rutinitas belaka; (4) perasaan (feeling) yaitu perasaan ini bermakna perasaan atau emosi atau kepekaan. Oleh karena itu pembelajaran dalam hal ini harus mampu menumbuhkan kepekaan sosial terhadap dinamika dan problematika kehidupan masyarakat (Muchith, 2008:73-74).

Teori konstruktivisme dipergunakan sebagai pendekatan untuk memaknai makna konsep ajaran Tri Hita Karana . Sebab, disekolah peserta didik sudah memiliki pengetahuan tentang konsep ajaran Tri Hita Karana yang di dapat dari pendidikan informal dalam keluarga dan jenjang pendidikan formal sebelumnya, sehingga pendidikan tentang konsep ajaran Tri Hita Karana yang diberikan disekolah akan menjadi penguat dari pengetahuan yang dimiliki sebelumnya. Pembelajaran tentang konsep ajaran Tri Hita Karana disekolah di konstruksi agar pengetahuan yang bersifat teori dapat direalisasikan dalam kehidupan kesehari-hari. Dengan modifikasi dan intergrasi materi nilai-Karakter yang terkandung dalam konsep ajaran Tri Hita Karana sangat diperlukan agar nilai-nilai itu menjadi sebuah kenyataan yang dapat mengantarkan terbangunnya sumber daya manusia (SDM) yang berkarakter.

Implementasi konsep ajaran Tri Hita Karana dalam proses pembelajaran disekolah senantiasa diamalkan dalam kehidupan pergaulan sehari-hari oleh siswa disekolah maupun dimasyarakat serta berupaya memaknai dan menyayangi jasmani dan rohani, mampu beradaptasi dan hidup bersama dengan orang lain dan makhluk lain, menjaga lingkungan berbhakti kepada Tuhan Yang Maha Esa. NilaiKarakter yang terkandung pada ajaran Tri Hita Karana juga merupakan bagian integral dari pengembangan sains dan teknologi yang dikembangkan melalui seluruh proses pembelajaran pada mata pelajaran yang sesuai dengan kurikulum yang berlaku di semua unit dan jenjang pendidikan sekolah.

Depdiknas (2011) memaparkan bahwa proses pendidikan karakter didasarkan pada totalitas psikologi yang mencakup seluruh potensi individu manusia (kognitif, apektif, psikomotorik), dan fungsi totalitas sosiokultural tersebut dikelompokkan menjadi empat, diantaranya: (1) olah pikir (intellectual development); (2) olah hati (spiritual and emotional); (3) olah rasa dan karsa (Affective and creativity development); (4) olah raga dan kinestetik (physical and kinestetic development).

Pengkatagorian di atas, didasarkan pada pertimbangan bahwa pada hakekatnya perilaku seseorang yang berkarakter merupakan perwujudan fungsi totalitas psikologi yang mencakup seluruh potensi individu manusia dan fungsi totalitas sosiokultural dalam konteks interaksi (dalam keluarga, satuan pendidikan, dan masyarakat), dan berkembang sepanjang hayat. Proses pendidikan karakter melalui konsep ajaran Tri Hita Karana disekolah adalah dengan cara mendidik siswa untuk selalu berbhakti kepada Tuhan Yang Maha Esa (Ida Sang Hyang Widhi Wasa) dengan membiasakan siswa untuk selalu berdoa (Trisandya) sebelum proses pembelajaran dimulai, selalu bersembahyang di pura yang ada disekolah, mengajarkan siswa untuk selalu sembahyang di rumah masing-masing sebelum berangkat kesekolah. Dengan mengajarkan rasa bhakti kepada Tuhan peserta didik diberikan pemahaman bahwa bhakti adalah merupakan kasih sayang yang mendalam kepada Tuhan. Dengan selalu berbhakti kepada Tuhan maka peserta didik akan selalu memiliki sikap toleran terhadap pelaksanaan ibadah agama lain, dan siswa akan mampu hidup rukun dengan temantemannya disekolah maupun dengan pemeluk agama lain.

Proses pendidikan karakter melalui implemetasi ajaran Tri Hita Karana disekolah adalah melalui: (1) pendidikan dan latihan (seperti soft skill, enterprenership); (2) mengajak siswa untuk selalu menggali ilmu pengetahuan dan keterampilan dari 
orang-orang yang sukses (seperti pengusaha sukses, guru atau dosen yang sukses); (3) mengarahkan atau mengajak siswa untuk selalu bergaul dalam lingkungan orang-orang yang unggul dan orang-orang yang pintar; (4) mengarahkan dan mengajak siswa agar selalu yakin dan percaya bahwa apa yang kita lakukan dengan ikhlas dan penuh welas asih akan selalu dilindungi oleh Tuhan Yang Maha Esa; (5) mengajak dan memberikan contoh kepada siswa bahwa dengan membantu sesama manusia dengan cara beryajna akan memberikan kebahagiaan yang sangat mulia dan Tuhan akan selalu melingdungi kita; dan (6) mengajak atau memberikan contoh dengan cara selalu hidup bersih dengan cara tidak membuang sampah sembarangan dan memberikan pengetahuan bahwa dengan membuang sampah sembarangan akan dapat membuat alam rusak, dan sebaliknya jika selalu hidup bersih dan membuang sampah pada tempatnya maka hidup kita akan damai dan sejahtera karena Tuhan akan selalu melindungi kita semua.

\section{KESIMPULAN}

Membangun karakter dan watak anak-anak melalui pendidikan mutlak dilakukan, pendidikan karakter melalui pembelajaran pengetahuan semata, akan tetapi lebih dari itu adalah penanaman moral, dan nilai-nilai etika. Kerja sama antara sekolah dan keluarga perlu ditingkatkan supaya tidak terjadi kontradiksi atau ketidakselarasan antara nilai-nilai yang harus dipegang teguh oleh anak-anak disekolah dan yang harus mereka ikuti di lingkungan keluarga ataupun di lingkungan masyarakat tempat keberadaan si anak. Konsep Tri Hita Karana sebagai upaya membangun karakter siswa disekolah. Agar semua siswa mampu memahami kehidupan dengan baik dan selalu mempunyai hubungan yang baik dengan Tuhan, antara manusia dengan sesama manusia, dan antara manusia dengan alam lingkungannya. Konsep Tri Hita Karana sebagai upaya dalam membangun karakter siswa disekolah adalah merupakan konsep ajaran agama Hindu sebagai falsafat hidup umat Hindu dalam membangun sikap hidup yang benar dalam menjaga keharmonisan antara percaya dan bhakti pada Tuhan, mengabdi pada sesama manusia dan menyayangi alam lingkungan berdasarkan yajna. Tujuan pendidikan karakter melalui implementasi konsep ajaran Tri Hita Karana adalah: (1) mendorong tercapainya keberhasilan belajar peserta didik, serta bertujuan untuk mendewasakan peserta didik agar memiliki kepekaan terhadap nilai-nilai moral yang paripurna, serta seimbang antara kecerdasan intelektual, emosional, dan spiritual; (2) bagi para pendidik/guru diharapkan menjadi primer efek, yang dapat memberi serta menjadikan dirinya suri teladan bagi semua lingkungan sekolah, terutama kepada siswa/peserta didik; (3) dapat menciptakan manusia indonesia yang seutuhnya, yaitu manusia yang beriman dan bertakwa kepada Tuhan Yang Maha Esa, berakhlak mulia, memiliki tangging jawab tinggi dalam menjalankan kehidupan ini; (4) untuk dapat menumbuhkembangkan kemampuan dasar dari peserta didik agar selalu berpikir cerdas, bersikap religius, berperilaku yang berakhlak mulia, mencintai sesama manusia, bermoral, peduli terhadap lingkungan, berbuat sesuatu yang baik yang bermanfaat bagi diri sendiri, keluarga, dan masyarakat, membangun kehidupan bangsa yang multikultur, membangun peradaban bangsa yang cerdas, berbudaya yang luhur, membangun sikap warga negara yang cinta damai, kreatif, mandiri, maupun hidup berdampingan dengan bangsa lain; dan (5) untuk membentuk manusia yang mempunyai kepribadian yang luhur dan mempunyai budi pekerti yang tinggi, selalu hidup harmonis dengan sesama manusia, dengan alam sekitarnya maupun adanya keharmonisan hubungan manusia dengan penciptanya yaitu Tuhan Yang Maha Esa. Sehingga setiap manusia pada akhirnya mendapatkan kebahagiaan lahir maupun batin. Dengan karakter mulia setiap usaha dan kegiatan yang dilakukan oleh manusia akan mendapatkan ketentraman, keamanan serta kedamaian hidup "jagadhita". 


\section{Daftar Rujukan}

Amin, Maswardi Muhammad. 2011. Pendidikan Karakter Anak Bangsa. Jakarta: Boduose Media Jakarta.

Aryadharma, Ni Kadek Surpi. 2005. Melahirkan Generasi Berkarakter Dewata. Kiat sukses Siswa Menurut Hindu. Denpasar: Pustaka Bali Post.

Depdiknas. 2011. Model Silabus dan Rencana Pelaksanaan Pembelajaran Pendidikan Agama Hindu. Jakarta: Badan Standar Nasional Pendidikan.

Donder, I Ketut. 2007. Kosmologi Hindu, Penciptaan, Pemeliharaan, dan Peleburan Serta Penciptaan Kembali Alam Semesta. Surabaya: Paramita.

Griffith, R.T.H. 2005. Sāma Veda Samhitā (diterjemahkan oleh Dewanto). Surabaya: Paramita.

Griffith, R.T.H. 2005. Yajur Veda Samhitā (diterjemahkan oleh Dewantoro). Surabaya: Paramita.

Herawan, K. D., \& Sudarsana, I. K. (2017). Relevansi Nilai Pendidikan Karakter Dalam Geguritan Suddhamala Untuk Meningkatkan Mutu Pendidikan Di Indonesia. Jurnal Penjaminan Mutu, 3(2), 223-236.

Idi, H. Abdullah. 2011. Sosiologi Pendidikan Individu, Masyarakat, dan Pendidikan. Jakarta: Rajawali Pers.

Lickona, Thomas. 2013. Pendidikan Karakter Panduan Lengkap Mendidik Siswa Menjadi Pintar dan Baik. Bandung: Nusa Media.

Mantra, Dharmawijaya. I. B. Rai. Koran Bali Post 10 Nopember 2012. Terjadi Pergeseran Etika di Kalangan Remaja. Denpasar: Bali Post.

Megawangi, Ratna. 2004. Pendidikan Karakter: Solusi Tepat untuk Membangun Bangsa. Bogor: Indonesia Heritage Foundation.

Muchith, Saekhan. 2008. Pembelajaran Kontekstual. Semarang: RaSail Media Group.
Ngurah, I Gusti Made, dkk. 2005. Buku Pendidikan Agama Hindu untuk Perguruan Tinggi. Surabaya: Paramita.

Narayana, Swami Sathya. 2010. Melaksanakan Gita Sehari-hari Jalan Menuju Tuhan (alih bahasa I Wayan Sadia). Surabaya: Paramita.

Oka, Ida Pedanda Gde Nyoman Jelantik. 2009. Sanatana Hindu Dharma. Denpasar: Widya Dharma.

Parimartha, I Gde, dkk. 2011. Nilai Karakter Bangsa dan Aktualisasinya dalam Kehidupan Masyarakat Bali. Denpasar: Udayana University Press.

Pudja, G. 1999. Bhagawadgita (Pancama Veda). Surabaya: Paramita.

Sudharta, Tjok Rai. 2009. Sarasamuccaya Smerti Nusantara (Berisi Kamus Jawa Kuno-Indonesia). Surabaya: Paramita.

Syarbini, Amirulloh. 2012. Buku Pintar Pendidikan Karakter, Panduan Lengkap Mendidik Karakter Anak di Sekolah, Madrasah dan Rumah. Jakarta: as@-Prima Pustaka.

Titib, I Made. 1999. Veda Sabda Suci Pedoman Praktis Kehidupan. Surabaya: Paramita.

Titib, I Made. 2006. Menumbuhkembangkan Pendidikan Budhi Pekerti Pada Anak (Perspektif Agama Hindu). Denpasar: Pustaka Bali Post.

Undang-Undang RI No. 20 tahun 2003. Tentang Sistem Pendidikan Nasional. Jakarta: Departemen Pendidikan Nasional.

Wiana, I Ketut. 2007. Tri Hita Karana Menurut Konsep Hindu. Surabaya: Paramita.

Wiyani, Novaqn Ardy. 2012. Manajemen Pendidikan Karakiter Konsep dan Aplikasikasinya di Sekolah. Yogyakarta: PT Pustaka Insan 